Situando o debate

\title{
Política e saúde: conceitos básicos e abordagens teórico- metodológicas para análise política em saúde bucal
}

\author{
Sônia Chaves \\ Samuel Moysés
}

\section{SciELO Books / SciELO Livros / SciELO Libros}

CHAVES, S., and MOYSÉS, S. Política e saúde: conceitos básicos e abordagens teórico-metodológicas para análise política em saúde bucal. In: CHAVES, S.C.L. Política de saúde bucal no Brasil: teoria e prática [online]. Salvador: EDUFBA, 2016, pp. 13-46. ISBN 978-85-232-2029-7.

https://doi.org/10.7476/9788523220297.0002.

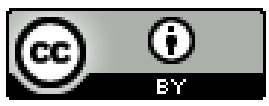

All the contents of this work, except where otherwise noted, is licensed under a Creative Commons Attribution 4.0 International license.

Todo o conteúdo deste trabalho, exceto quando houver ressalva, é publicado sob a licença Creative Commons Atribição 4.0. 



\section{Política e saúde}

CONCEITOS BÁSICOS E ABORDAGENS TEÓRICO-METODOLÓGICAS PARA ANÁLISE POLÍTICA EM SAÚDE BUCAL

Sônia Chaves e Samuel Moysés

\section{Apresentação}

O estudo de análise de políticas públicas de saúde bucal no Brasil é recente e com incipiente produção de conhecimento, ainda que haja um importante esforço teórico empreendido na primeira década e meia do século XXI. O que caracteriza essa incipiente produção de parte desse conjunto de publicações é a ausência de teorias de fundo do campo sociológico ou das ciências políticas, capazes de iluminar o percurso da política de saúde bucal com maior poder heurístico. Quanto a isso, é preciso reconhecer que a fortuna crítica, dessa ou de qualquer área de conhecimento, só avança para níveis de maior consistência quando incorpora fundamentos epistemológicos de maior envergadura. Nesse sentido, este capítulo buscou analisar, ainda que de forma não exaustiva, um conjunto de contribuições do marxismo, sociologia e ciência política para essa área temática em crescimento, focando nas categorias de Estado, poder, política pública, política social e de saúde e ciclo da política, buscando trazer a contribuição de alguns pensadores e pesquisadores dessa temática. Além disso, buscou mapear a produção científica nacional focando na fase da entrada na agenda e formulação do ciclo da política, na tentativa de elucidar os principais 
achados e lacunas ainda existentes que possam problematizar e orientar estudos futuros. É também um guia teórico-metodológico para aqueles que se iniciam na temática ou que necessitam de uma síntese sobre a mesma na área de saúde bucal. Cabe lembrar o sentido da produção de conhecimento, conforme aponta Bourdieu (2004, p. 65-66):

É possível pensar com um pensador contra esse pensador. Por exemplo, construí a noção de campo contra Weber e ao mesmo tempo com Weber. [...] Acho que é possível pensar com Marx e contra Marx ou com Durkheim contra Durkheim, e também, é claro, com Marx e Durkheim contra Weber, e vice-versa. É assim que funciona a ciência. [...] Por definição, a ciência é feita para ser superada [...] e Marx reivindicou suficientemente o título de cientista para que a homenagem a lhe ser feita seja a de se usar o que ele fez para superar o que ele acreditou ter feito.

\section{Política e Estado Moderno}

A política é dimensão essencial de toda atividade humana. Todos fazemos política e muitos intelectuais e pensadores se ocuparam de defini-la, ao longo do tempo, tais como: Platão e Aristóteles na Grécia Antiga; Maquiavel, no Renascimento, com o livro O Príncipe; Hobbes e Locke nos séculos XVI e XVII, até alcançar os séculos XVIII e XIX com Hegel, Augusto Comte, Alexis de Tocquevile, John Stuart Mill que são defensores e teóricos do liberalismo político; Karl Marx, que lançará as bases de toda a teorização de esquerda que adentrará pelo século XX e influenciará revoluções e pensadores como Hannah Arendt, Antonio Gramsci, Norberto Bobbio, os pensadores da Escola de Frankfurt, entre outros. No presente capítulo, será adotada a visão de Bobbio (1991), para quem política é "atividade humana ligada à obtenção e manutenção dos recursos necessários para o exercício do poder sobre o homem".

O termo grego "política" deriva da "politeia", já utilizada por Platão no livro de sua autoria que aborda a cidade, A República, caracterizando a organização do mundo grego em cidades-estado; e politikos, sendo a arte de governar tais cidades. (PLATÃO, 2006) Com o tempo, a luta pelo poder passou a ser uma das características mais marcantes da política, chegando mesmo em muitos casos a ser a única real motivação dos políticos. Pode-se falar do "homem político" como aquele que vive para a política, que lhe dá sentido de vida e alimenta seus projetos ideológicos, e também pode-se falar do homem que vive da política, 
como aquele que exerce a ação política no interior do Estado, dele tirando seu sustento material. (WEBER, 2014)

É preciso lembrar que, para Weber, um conceito fundante da teoria sociológica é a categoria "ação". A ação é um comportamento humano a que os indivíduos vinculam um significado subjetivo, sendo ação social quando está relacionada com outro indivíduo. A análise da teoria weberiana como ciência tem como ponto de partida a distinção entre quatro tipos de ação social: 1) a ação instrumental, com relação a um objetivo, é guiada para fins próprios racionalmente avaliados e perseguidos; é uma ação concreta que tem um fim especifico; 2) a ação racional, com relação a um valor, é aquela definida pela crença consciente no valor - ético, estético, religioso ou qualquer outro onde o ator age racionalmente aceitando todos os riscos, não para obter um resultado exterior, mas para permanecer fiel à sua honra; 3) a ação afetiva é aquela definida por uma reação emocional do ator em determinadas circunstâncias e não em relação a um objetivo ou a um sistema de valor; 4) a ação tradicional é aquela ditada pelos hábitos, costumes, crenças em que o ator não precisa conceber um objeto, ou um valor, nem ser impelido por uma emoção, mas obedece a reflexos adquiridos pela prática. (WEBER, 2004) Nesta última acepção, a ação lembra o conceito de habitus de Bourdieu. Certamente, por reconhecer a importância do conceito weberiano de ação, Jürgen Habermas (1984) concede a Weber um papel fundamental em sua "teoria da ação comunicativa", descrevendo a sociologia weberiana da racionalização.

Aqui, há outro aspecto importante, pois falar do conceito weberiano de homem político (e, obviamente, de sua ação na esfera pública) é, necessariamente, situá-lo em um processo histórico mais vasto: o de racionalização. Esse conceito significa a presença, na modernidade ocidental, de uma atitude de instrumentalização que os agentes sociais têm para com o mundo, para com os outros e para consigo, com vistas à consecução de determinados fins ou valores. Tal instrumentalização modernizadora diferencia essa época, quanto ao sistema político que então se desenvolve, em contraposição a outros períodos históricos nos quais os processos de dominação ou autoridade são de outra natureza (como a tradicional e a carismática). Aqui estamos diante da natureza burocrática.

O tipo de autoridade (burocrática ou racional-legal) é justificado pela técnica, pela justiça, pela lei e pela meritocracia. Max Weber foi o primeiro teórico que, em uma análise voltada para a estrutura, acreditava que a burocracia era a 
organização por excelência, suportada por uma elite que, para manter o poder e a legitimidade, desenvolveu um determinado aparelho administrativo para servir de suporte à sua autoridade. Autores como Robert Merton encontraram limitações na obra de Weber, partindo para uma análise crítica da realidade descrita por ele. Merton menciona as disfunções da burocracia frequentemente exageradas pelos leigos quando fazem "sociologia espontânea": internalização das regras e o apego aos regulamentos, o excesso de formalismo e de papelório, a resistência a mudanças, a dificuldade no atendimento a clientes e os conflitos com o público. Na administração burocrática, os procedimentos sobrepõem-se à eficiência. A orientação é que o procedimento seja rigorosamente cumprido, mesmo que o resultado adquira onerosidade ou deixe de surtir efeito. Hannah Arendt (2001) é outra que se distancia de Weber, pois, enquanto na visão weberiana, o poder é uma ação estratégica em que o ator visa utilizar, da forma mais eficaz possível, os meios à sua disposição para atingir um fim previamente definido (isto é, submeter a vontade do outro à sua), para Arendt, o poder (e a ação política) é um fim em si mesmo e, dessa forma, não pode ser instrumentalizado em nome de qualquer outro fim. Sendo uma ação política, cujo sentido último é sempre a interação entre os homens, o poder não pode ser avaliado pelo seu resultado final, mas valorizado por si mesmo.

A política pode ser compreendida, no seu sentido amplo, como as relações de poder e dominação entre os agentes sociais. Contudo, neste capítulo, trataremos do conceito de política como ação diretiva do Estado. Precisamos então compreender o Estado, conforme visto por Pierre Bourdieu (2014), como um objeto impensável, pela sua imensa influência sobre todas as nossas categorias de percepção do mundo social do qual todos nós fazemos parte, desde o conceito de calendário até a classificação das profissões, por exemplo, que, em última instância, são categorias produzidas pelo próprio Estado.

O Estado moderno, como o compreendemos hoje, já foi problematizado por importantes pensadores e sociólogos - Antonio Gramsci, Max Weber, Karl Marx e Pierre Bourdieu - e pode ser entendido de diferentes maneiras. Bourdieu parte da definição dada por Weber (2014), para quem o Estado moderno ou contemporâneo é aquele onde se situa uma comunidade humana que reivindica para si o monopólio do uso da violência física legítima. É o lugar da posse do monopólio da violência legítima. E a política é a forma de participação no poder ou a luta para se incluir nessa distribuição de poder entre os grupos ao interior do Estado. Por outro lado, Bourdieu (2014) complementa afirmando 
que o Estado, além de monopolizar o uso da força física, é também aquele que exerce a violência simbólica legítima. É o lugar do monopólio da violência física e simbólica legítima. (BOURDIEU, 2014) Ou seja, é aquele que produz o discurso universal aceito e reconhecido como legítimo entre os dominados, mesmo em sociedades democráticas. Essa legitimação ocorre pelos Atos do Estado, como expressão da alquimia social infinitamente poderosa, onde repousa o consentimento. Portanto, é importante ficar sempre alerta quando pensamos ou escrevemos ou estudamos o Estado.

O Estado é essa ilusão bem fundamentada, esse lugar que existe essencialmente porque se acredita que ele existe. Essa realidade ilusória, mas coletivamente validada pelo consenso, é o lugar para o qual somos remetidos quando regredimos a partir de certo número de fenômenos diplomas escolares, títulos profissionais ou calendário. De regressão em regressão, chegamos a um lugar que é fundador de tudo isso. (BOURDIEU, 2014, p. 38)

Já foi compreendido como lugar neutro destinado a servir ao bem comum e ao governo, o bem do povo, segundo Thomas Hobbes e John Locke. Mas também como aparelho de coerção, de manutenção da ordem pública em proveito dos dominantes, "balcão de negócios" da burguesia. (MARX; ANGELS, 1999)

O principal alerta é que o Estado não é sujeito. É importante fugir dessa armadilha, substituindo o Estado pelos seus Atos. Os atos políticos têm pretensão de provocar efeitos no mundo social (território físico e imaterial). E a política (pública), portanto, será um tipo de Ato do Estado, reconhecida como legítima pela crença na existência do princípio que a fundamenta (o ato), numa espécie de cadeia de delegações infinita que faz com que o aparelho do Estado funcione.

Assim, a política é o resultado desse processo de delegação. Envolve politics - referente à existência e ao exercício do poder como a sua natureza, estrutura, distribuição e lutas -, mas também policy - que diz respeito ao estabelecimento de diretrizes, planos e programas. Em português, a palavra "política" envolve tanto as dimensões do poder quanto das diretrizes. Política pública refere-se ao exercício do poder (politics) e às intervenções planificadas (policy) na esfera pública, mas com repercussões na esfera privada. A política pública pode ter 
um caráter social, no sentido de enfrentamento de problemas sociais identificados pelos grupos interessados. Nesse caso, será uma política social.

\section{As questões relativas ao poder}

Falar de poder enquanto categoria não é tarefa fácil. Em capítulo dedicado à análise desse atributo, François Chazel (1995) define o poder como a capacidade de um determinado agente alcançar os resultados visados, de realizar as ações com êxito. Na vida social e política (ou seja, aquela que envolve o ponto de nosso interesse que é o Estado), o poder se reveste normalmente da forma de um poder sobre outros homens.

Empiricamente, atribuir poder a um determinado agente ou grupo de agentes seria analisar a produção dos efeitos pretendidos. Para Thomas Hobbes, reconhecendo o caráter mais filosófico de sua obra, o poder de um homem consiste na possibilidade de obtenção de um bem aparente no futuro (Leviatã, “Capítulo X"). Contudo, não podemos reduzir o poder ao seu exercício. Ele pode ser visto como uma capacidade, uma potencialidade duradoura. A concepção de poder como uma propriedade defende que este é detido por alguns agentes ou grupo de agentes, logo é substância. Contudo, o pensamento do poder numa concepção relacional é mais adequado, já que: 1) permite pensar que sua influência será variável em função dos agentes no tempo, ou seja, ainda que a sua propriedade se modifique; 2) permite também observar os processos da dinâmica subjacente às relações. Logo, é preciso considerar que o poder é exercício em relações de dominação.

Para Weber, o poder significa fazer triunfar em uma relação social a sua própria vontade, mesmo contra resistências. (WEBER, 2004) Ao apresentar o poder, Weber deixa clara a relação entre poder e dominação, poder e conflito. Há, portanto, que reconhecer nos três tipos de dominação legítima (tradicional, carismática e legal), a possibilidade do exercício do poder físico. Nesse sentido, tanto Max Weber (2004) como Pierre Bourdieu (2014) nos ajudam a compreender melhor as especificidades do poder político que é um componente essencial de qualquer sociedade, não sendo mero produto da dominação econômica. O poder político se distingue das demais formas de poder por três aspectos: 1) pelo seu caráter territorial; 2) tem à sua disposição toda uma série de sanções punitivas, coercitivas a que recorre ocasionalmente, constituindo-se na sua vertente coercitiva, de violência física; e 3) é resultado da alquimia 
do estado, de universalização dos discursos oficiais, constituindo-se na sua vertente simbólica.

Para Hannah Arendt, o poder não é atributo de um agente, mas o resultado da capacidade do agir em conjunto de um grupo, que produz consentimento ao seu interior e que leva à formação de uma vontade comum. Sua análise envolve o foco em grupos sociais e não em agentes específicos. (ARENDT, 2001) Essa análise foi útil no estudo das relações de poder na Política Nacional de Saúde Bucal (PNSB), no seu período de entrada na agenda e formulação, em 2003, que apontou a construção de um poder importante de um grupo militante que influenciou sua formulação. (ANDRADE, 2009)

Para Mário Testa (1992), um dos que pensaram o poder no setor saúde, este pode ser de três tipos: administrativo, técnico e político. Antes de tudo, é a capacidade de um em relação aos outros. O primeiro tipo seria essa capacidade de deter informações e manejo de recursos e processos. O segundo seria daqueles que manejam conhecimento técnico específico. O poder político seria o manejo ideológico de outros sujeitos. Para Testa, é bom destacar, a política pressupõe distribuição do poder entre os grupos sociais. (TESTA, 1992)

\section{Política pública e saúde}

Há farta literatura sobre políticas públicas e algumas falsas controvérsias. Um exemplo é a controvérsia em torno da diferença entre a abordagem estadista (state-centered policy-making), que considera que somente deve ser denominada como política pública aquela que emana dos agentes do Estado, e a abordagem multicêntrica (policy networks), que defende a ideia de que o importante é se o problema é de interesse público, em que, tanto os agentes no interior do aparelho governamental do Estado como os não governamentais, influenciam sua formulação e implementação. Essa controvérsia pode estar relacionada à origem disciplinar americana dos estudos sobre políticas públicas.

A política pública enquanto área de conhecimento e disciplina acadêmica nasce nos Estados Unidos, em contraposição à tradição europeia, que se concentrava mais na análise sobre o Estado e suas instituições do que na produção dos governos. Assim, na Europa, a área de política pública vai surgir como um desdobramento dos trabalhos baseados em teorias explicativas sobre o papel do Estado e de uma das mais importantes instituições do Estado - o governo -, produtor, por excelência, de políticas públicas. Nos Estados Unidos, ao contrário, a área surge no mundo acadêmico sem estabelecer relações com as bases 
teóricas sobre o papel do Estado, passando direto para a ênfase nos estudos sobre a ação dos governos, compreensível pelo seu nascimento ocorrer como subárea da ciência política.

Assim, a política pública nos Estados Unidos está focada na análise sobre a ação do governo e não do Estado. Devemos aqui diferenciar governo de Estado. Governo é um grupo que ganha uma eleição e fica por tempo determinado no poder. Já Estado é a estrutura, a instituição a qual o governo representa; é a nação politicamente organizada. Assim, tanto ações (o fazer) quanto inações (o não fazer) dos governos são passíveis de serem formuladas cientificamente e de serem analisadas por pesquisadores independentes.

E afinal, o que são políticas públicas? São conjunto de intervenções organizadas pelo Estado através de diferentes governos com a participação de agentes e instituições governamentais e não governamentais que visam enfrentar situações socialmente problemáticas, identificadas como necessidades sociais por diferentes grupos. Já a análise de políticas públicas é, resumidamente, o "campo do conhecimento que busca desvendar o 'governo em ação' e propor mudanças no rumo ou curso dessas ações". (SOUZA, 2007, p. 69) Logo, “a formulação de políticas públicas constitui-se no estágio em que governos democráticos traduzem seus propósitos e plataformas eleitorais em programas e ações, que produzirão resultados ou mudanças no mundo real". Ou seja, é o estudo do processo (do porquê e do como) e não das consequências.

Vale ressaltar que não devemos escolher primeiro a teoria e depois tentar encaixar o problema nela. A teoria deve ser apenas uma lente para nos auxiliar a compreender melhor a realidade. Esta necessita ser escolhida de acordo com o problema que queremos analisar. Nessa perspectiva, os elementos principais das políticas públicas são:

- A distinção entre o que o Governo pretende fazer e o que de fato faz;

- O envolvimento de diversos agentes e instituições (governamentais e não governamentais);

- A abrangência - não se limita a leis e regras;

- A ação intencional, planejada e de longo prazo;

- Os processos: entrada na agenda - decisão - proposição - implementação - execução - avaliação;

- É diferente de política social, que está focada nas consequências, os problemas sociais - a política social é um tipo de política pública e não o contrário. 
Portanto, esse espaço do conhecimento busca integrar quatro elementos: a política pública (policy); a dimensão do poder na política (politics); a sociedade política (polity); e as instituições que as regem. Tem como foco analítico a identificação do problema que a política visa corrigir; a chegada do problema ao sistema político (politics) e à sociedade política; o processo percorrido; e as instituições e regras que modelarão a decisão e a implementação da política pública.

No entanto, definições de políticas públicas, mesmo as minimalistas, guiam o nosso olhar para o lócus, onde os embates em torno de interesses, preferências e ideias se desenvolvem, isto é, os governos. As políticas públicas repercutem na economia e na sociedade, daí por que qualquer teoria da política pública precisa também explicar as inter-relações entre Estado, política, economia e sociedade.

De fato, a construção social do problema visto como de todos e seu enfrentamento é resultado da inter-relação entre os diferentes agentes situados nos distintos espaços sociais. Mas cabe ao Estado, lócus de dominação e construção do discurso universal, o papel importante na tomada de decisão em torno dos problemas sociais. (BOURDIEU, 2012)

\section{Política de saúde: conceitos básicos e seus instrumentos}

Política de saúde, um tipo de política pública e social, nesse capítulo é compreendida em acordo com a proposta de Paim (2003, p. 587):

[...] a ação ou omissão do Estado, através de uma resposta social diante de problemas de saúde e seus determinantes, materializada através de práticas ou ações de saúde voltadas para problemas e/ou necessidades na produção, distribuição e regulação de bens, serviços e ambientes que afetam a saúde de indivíduos e coletivos.

Essa política pode atender a demandas de grupos sociais interessados, mas é mais complexo que apenas responder a um grupo dominante específico. Possui uma dimensão do poder e outra da ação diretiva do Estado. Entre os instrumentos das políticas, como Atos do Estado, destacam-se os documentos institucionais que materializam decisões políticas, como leis, normas, decretos, portarias, planos, programas e projetos. Esses instrumentos visam produzir um efeito de legitimação simbólica. Políticas públicas (de saúde, como de 
qualquer outra área), após desenhadas e formuladas, desdobram-se em planos, programas, projetos, bases de dados e sistema de informação para pesquisas.

Não se defende aqui que o Estado (ou os governos que decidem e implementam políticas públicas ou outras instituições que participam do processo decisório) reflete tão somente as pressões dos grupos de interesse, como diria a versão mais simplificada do pluralismo. Também não se defende que o Estado opta sempre por políticas definidas exclusivamente por aqueles que estão no poder, como nas versões também simplificadas do elitismo, nem que servem apenas aos interesses de determinadas classes sociais, como diriam as concepções estruturalistas e funcionalistas do Estado. No processo de definição de políticas públicas, sociedade e Estado complexos como os constituídos no mundo moderno estão mais próximos da perspectiva teórica daqueles que defendem que existe uma "autonomia relativa do Estado", o que faz com que ele tenha um espaço próprio de atuação, embora permeável a influências externas e internas.

Apesar do reconhecimento de que outros segmentos que não os governos se envolvem na formulação de políticas públicas, tais como os grupos de interesse e os movimentos sociais, cada qual com maior ou menor influência a depender do tipo de política formulada e das coalizões que integram o governo, e apesar de certa literatura argumentar que o papel dos governos tem sido encolhido por fenômenos como a globalização, a diminuição da capacidade dos governos de intervir, formular políticas públicas e de governar não está empiricamente comprovada.

As políticas de saúde representam uma das principais parcelas dos investimentos sociais, juntamente com políticas de seguridade social e previdência, afetando todo o ciclo de vida. Porém, não deveriam ser vistas simplesmente como "gasto" social improdutivo. Sobre os sistemas de saúde contemporâneos, projetam-se tensões e pressões semelhantes às que encontramos noutras áreas sociais, quando se trata de lidar com reformas estruturais: aumento continuado da despesa, pressões demográficas, arrefecimento do crescimento econômico e constrangimentos fiscais. Na área da saúde, a complexidade econômico-financeira que decorre em grande parte da inovação tecnológica e terapêutica e a centralidade do poder dos profissionais de saúde, revertido em "autonomia", tornam-se fatores cruciais. Dessas especificidades, resulta um conjunto de desafios à mudança nas políticas. 


\section{Possíveis abordagens teóricas e metodológicas de políticas públicas de saúde}

O estudo desse processo político da política tem sido objeto de investigação da ciência política e também da sociologia. A análise do processo político para o enfrentamento de um determinado problema de saúde, por exemplo, na perspectiva da ciência política (considerada uma das três áreas das ciências sociais juntamente com a sociologia e antropologia), tem sido apresentada comumente em quatro ou cinco etapas, ainda que haja mais variações: 1) construção social do problema; 2) definição ou entrada na agenda; 3) formulação; 4) implementação; e 5) avaliação. Essas etapas fazem parte do ciclo da política pública, considerada uma abordagem metodológica consolidada para análise política (Figura 1).

Figura 1 - Ciclo da política em cinco momentos principais

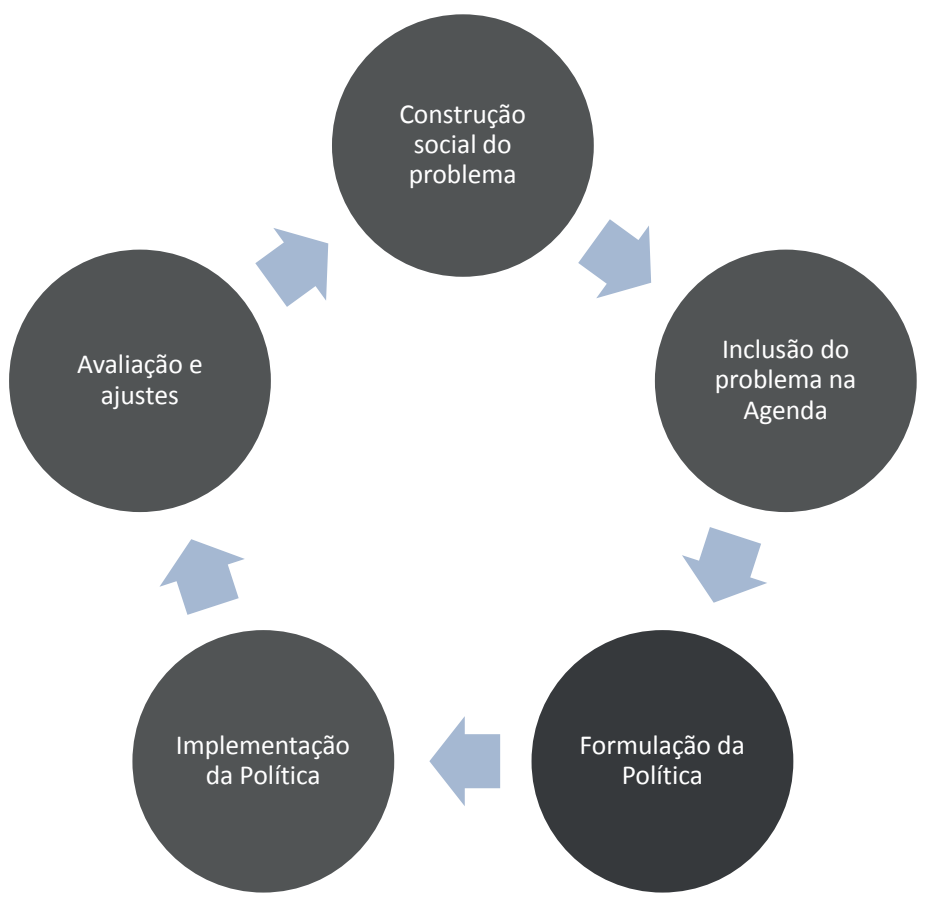

Fonte: elaboração dos autores. 


\section{Ciclo da política}

O ciclo da política pública é considerado um processo dinâmico e histórico. A principal contribuição dessa abordagem foi permitir ver que o curso da política não é um processo linear. Cada etapa tem dinâmica própria com diferentes influências dos agentes governamentais e não governamentais, das instituições envolvidas, bem como da conjuntura política e econômica. Ainda, fornece um quadro de referência para a análise processual ao atribuir funções específicas às diversas fases do processo político-administrativo.

Nesse sentido, teorias influentes na ciência política incluem a análise de múltiplos fluxos (multiple-streamstheory) de Kingdon (1995), cujo foco é a definição da agenda, em que há processos e fluxos independentes na priorização de problemas, na seleção de alternativas de políticas e na decisão sobre qual alternativa será eleita para a formulação. Esses momentos seriam, portanto, independentes e determinados por múltiplos processos.

A construção da agenda, ou seja, sua definição refere-se ao momento da entrada do problema como prioridade na agenda governamental. Cabe lembrar a existência de três tipos de agenda: a) agenda sistêmica ou não governamental, ou seja, aquela das prioridades dos atores fora do governo; b) agenda institucional ou governamental, ou seja, daqueles temas e problemas importantes para os agentes governamentais; e 3) agenda decisória ou política, aquela que realmente permanece, sendo ou do governo ou de fora dele.

Para Kingdon (1995), na primeira etapa da definição da agenda, o problema, entre muitos presentes, disputa a atenção da equipe dirigente e é então priorizado, numa provável janela de oportunidade. Ou seja, a agenda decisória corresponderá à definição de um conjunto de problemas que serão priorizados pelas autoridades governamentais, constituindo objeto de decisão política. A estatística e a epidemiologia, por exemplo, são ferramentas colocadas para enfatizar determinado problema, sendo instrumento de legitimação da agenda decisória, podendo aumentar o poder dos especialistas, dos empreendedores de política, já que reforçam a construção social do problema a ser enfrentado no período de governo.

Já na etapa de formulação da política, ao interior do governo, formulam-se tipos de soluções para os problemas, consistindo na investigação do problema e na busca de opções e alternativas para sua resolução. O estudo das diferentes alternativas é muito comum ao interior do legislativo e executivo, por exemplo. Nesse caso, a formulação terá forte influência dos especialistas de vários tipos 
que estudam o tema. No caso da saúde, o papel desempenhado pelos estudos de saúde pública, medicina ou odontologia, "baseado em evidências científicas" na formulação e avaliação dos resultados da política merece aprofundamento em estudos futuros. Críticas ao "centramento dentário" estão presentes no estudo de Pires e Botazzo (2015), onde, na análise histórica das políticas de saúde bucal no Brasil, mostrou que, desde os anos 1950, o setor público reproduz acriticamente a odontologia biologicamente centrada como modus operandi, mas com insuficiente resposta às necessidades. Esse estudo, a partir da perspectiva da teoria de Michel Foucault na obra Arqueologia do saber, também revelou o foco da política na redução de índices epidemiológicos de doenças com um modelo tecnológico e arranjos tecnológicos no processo de trabalho muitas vezes exitoso, mas não tem produzido suporte social para a autonomia dos sujeitos. Cabe refletir se a retórica das palavras na formulação é traduzida em ações concretas.

A etapa da implementação é uma das mais problemáticas, independente da abordagem teórica. (FISHER; MILLER; SIDNEY, 2007; PINELL, 2011) É, na verdade, o momento de colocar uma determinada solução em prática e envolve uma série de sistemas ou atividades da administração pública como os sistemas gerenciais, operacionais, de informação, entre outros. Nesse momento, uma diretriz pode ser rejeitada, modificada e alterar o argumento central da política, gerando novas negociações e formulações, reiniciando o ciclo. Para Paim (2002, p. 150), a implementação da política (sua institucionalização e mudança) “depende não apenas da correlação de forças políticas que dirigem ou pressionam o Estado e seus aparelhos, mas também da distribuição do poder ao interior do aparato estatal e das formas concretas de organização do processo de trabalho nas instituições”. Logo, estudar que tipo de Estado é o Estado brasileiro, sua história e sua determinação sobre as organizações é tarefa importante. Os estudos de Vianna (1988) e Assis (2006) são bons exemplos concretos de análises da implementação da atenção à saúde bucal no Brasil e as características do Estado brasileiro. As categorias desenvolvidas por Antonio Gramsci de revolução passiva e transformismo têm sido lembradas para explicar a natureza do Estado brasileiro no sentido das típicas revoluções burguesas de cima para baixo, sem participação popular onde se mantém a hegemonia a partir do "mudando sem transformar", transformando para não mudar. Já o transformismo se refere à absorção de indivíduos ou grupos ativos que pareciam irreconciliavelmente inimigos pelos grupos dominantes, manifestando-se em transformações das 
ideias e práticas dos grupos e intelectuais de esquerda em direção as ideias hegemônicas. (GRAMSCI, 1978)

A implementação de uma política dependeria de muitos fatores como transferência do projeto formulado para equipes de governo capazes de implementá-la, sua formulação clara e alocação de recursos associada à boa coordenação pelos burocratas (atores governamentais) na sua execução (FISHER; MILLER; SIDNEY, 2007), bem como de uma boa articulação entre o projeto, a capacidade de governo e sua governabilidade no nível local. (MATUS, 1996) A policy arena, ou seja, os diferentes agentes envolvidos com sua implementação, o grau de participação dos implementadores e grupos interessados poderiam significar maior êxito da mesma.

Quanto maior a mudança/transformação proposta pela política, provavelmente maiores serão as dificuldades de implementação. Ou seja, caso o propósito de governo seja de transformação (TESTA, 1995), sua capacidade de governo (MATUS,1996), sua organização e método deverão ser mais mobilizados. Sabatier (2007), também propõe uma análise considerando a implementação de cima para baixo ou debaixo para cima (top-down e bottom-up implementation), ou uma síntese dos dois. Há indícios de que a implementação ocorreria mais "de cima para baixo" do que o contrário, refletindo valores e interesses das burocracias estatais, dos especialistas no governo. (WALT et al., 2008)

Na etapa da avaliação, Sabatier (2007) sugere que "uma década ou mais" é a duração mínima da maioria dos ciclos de política, de emergência de um problema a seu enfrentamento com a implementação para uma "avaliação razoavelmente justa" de impacto. As avaliações são muito desejadas, mas nem sempre são realizadas. E mesmo quando realizadas, suas evidências são um elemento apenas para a tomada de decisão no processo político. Avaliação consiste sempre num julgamento de valor a respeito de uma intervenção ou qualquer dos seus componentes, visando à tomada de decisão. Contudo, ajustes são realizados pelos agentes envolvidos em sua implementação, independente das avaliações. A avaliação tem sido considerada um dos tipos possíveis de julgamento que se faz sobre as práticas sociais (VIEIRA-DA-SILVA, 2014), sendo que a política, como um conjunto de práticas articuladas, é objeto de julgamento do mérito em responder às necessidades sociais pretendidas.

Não existe uma proposta ou modelo único ou consensual para o processo de produção e análise do curso de uma determinada política, e sim variadas correntes de pensamento ou abordagens teóricas. Aqui, centraremos brevemente 
em três delas: o neoinstitucionalismo, a abordagem sociológica de análise de políticas públicas de saúde e as correntes marxistas e neomarxistas.

\section{O neoinstitucionalismo e as políticas de saúde}

O neoinstitucionalismo tem como foco o papel das instituições, que são consideradas como estruturas intermediárias que realizam a mediação da relação entre Estado e sociedade. (LIMA; MACHADO; GERASSI, 2011) Nesse sentido, é preciso elucidar o papel das instituições na determinação de resultados sociais e políticos decorrentes da formulação, implementação e avaliação da política pública. Ou seja, as instituições importam, podem ser fortes.

O conceito de instituição, no entanto, vai além de um lugar físico. As regras de conduta, as formas de constrangimento, a ordem social que rege o funcionamento de uma sociedade, leis fundamentais por que se rege um país, são instituições. Seria, portanto, um conceito mais amplo que organizações, que se referem aos grupos políticos (partidos, governos), econômicos (sindicatos, cooperativas), sociais (igrejas, associações profissionais, clubes) e educacionais (colégios, universidades), por exemplo. (LIMA; MACHADO; GERASSI, 2011) Cabe destacar que, sob o rótulo de neoinstitucionalismo, há uma diversidade de correntes e abordagens. São estudos que geralmente se concentram na análise de organizações.

O tema central é a relação entre estrutura e agente, e qual desses polos é o dominante. Ou seja, seria possível apontar que uma instituição estrutura a ação humana, num sentido mais ou menos determinista, de modo a produzir um modelo normalizado de comportamento? Ou, ao contrário, elas mesmas são produto dos modelos de comportamento e disposição dos agentes? (GUIDDENS, 1978) Veremos mais adiante que Pierre Bourdieu (2014) e Patrice Pinell (2011) podem nos ajudar a elucidar essa dualidade estrutura e agente.

\section{Abordagem sociológica de políticas de saúde}

As teorias de análise sociológica de políticas públicas de saúde têm sugerido outras abordagens para a compreensão e explicação do desenvolvimento da política. A sociologia reflexiva de Pierre Bourdieu tem contribuído com a conciliação entre a importância, tanto das estruturas quanto da posição dos agentes na explicação sociológica dos fenômenos. (BOURDIEU, 2003) Agente, segundo Pierre Bourdieu, rompe com a negação do sujeito, já que na filosofia 
do sujeito, este é concebido como ser estático, fora do jogo de interesses do campo. O agente é o ser que age e luta dentro do campo de interesses. Nessa perspectiva, a mudança das estruturas sociais passa pela ação social dos agentes ao interior de cada espaço social ou campo, sendo o habitus, essa mediação entre o agente e o campo.

No conceito de espaço social ou campo, aquilo que comumente se denomina sociedade, na verdade, é constituído de diversos microcosmos denominados "espaços sociais", no interior dos quais os agentes ocupam posições distintas relacionadas aos capitais acumulados do tipo cultural, político, econômico, social, entre outros. O campo é um tipo específico de espaço social com autonomia relativa em relação aos demais campos, com leis próprias e onde os agentes compartilham habitus comuns, constituindo uma illusio específica. O habitus é "um sistema de disposições duráveis e transponíveis socialmente incorporadas que, integrando todas as experiências passadas, funciona a cada momento como uma matriz de percepções, de apreciações e de ações". (BOURDIEU, 2003, p. 63)

O illusio, palavra originada de ludus (jogo), significa estar no jogo, estar envolvido no jogo, levar o jogo a sério, estar preso ao jogo que vale à pena jogar, dar importância a um jogo social, perceber que o que se passa aí é importante para os envolvidos, para os que estão nele, é reconhecer o jogo e reconhecer os alvos. (BOURDIEU, 1996) Ao desenvolver o conceito de illusio, Bourdieu afirma que os jogos sociais são jogos que se fazem esquecer como jogos. Illusio é, portanto, essa relação de encantamento com o próprio jogo, resultado da relação entre as estruturas mentais, as disposições incorporadas e as estruturas objetivas do espaço social. (BOURDIEU, 1996)

O espaço social é o espaço onde se joga o jogo e é expressão da estrutura de relações geradas pela distribuição de diferentes espécies de capital dos agentes. Nesse caso, o espaço social é aquele considerado como espaço de relações de poder entre agentes e instituições envolvidas em torno de um objetivo comum em lutas concorrentes. (PINELL, 2011) Nesse sentido, dentre os diferentes tipos de capital dos agentes, o capital social é considerado um capital de relações, de ganhos associados à existência de uma rede conectada atual e potencial, de pertencimento e associação a um grupo. Cabe destacar que o capital é a energia social do acúmulo histórico do agente ou instituição que garante posições distintas no espaço social de luta. (BOURDIEU, 1996) 
O capital simbólico, por outro lado, é uma forma de capital que nasce da relação entre uma espécie qualquer de capital e os agentes socializados de maneira a conhecer e reconhecer essa espécie de capital. (BARROS, 2013) O capital político seria essa capacidade de mobilização de um agente ou instituição/organização, como espécie de capital social e simbólico, obtido a título pessoal ou institucional. É também, portanto, de uma organização detentora desse tipo de capital, como ministérios específicos, partidos, associações ou sindicatos, conforme proposto por Barros (2013).

Para Bourdieu (2014), o Estado é esse espaço onde a política é legitimada e lugar dos dominantes dos diferentes campos sociais. O Estado é o lugar onde os atos políticos com pretensões de efeito no mundo social são dotados de uma autoridade que, gradualmente, por uma série de delegações em cadeia, remete a um lugar último, o próprio Estado, produzindo um discurso universal, de legitimação, lugar do monopólio da violência física e simbólica. (BOURDIEU, 2014)

Assim, Patrice Pinell (2011), numa abordagem sociológica do espaço de luta contra flagelos sociais como o câncer, a aids e o abuso de drogas, analisou a intervenção do Estado como resposta social contra esses flagelos, utilizando categorias para explicar a gênese das políticas, vinculando-a às preocupações sociais, ao espaço e à entrada de novos agentes especializados e instituições. $\mathrm{O}$ autor fundamentou sua análise em oito proposições explicitadas na gênese e na evolução ou implementação de políticas de saúde.

A construção social de um problema como problema é um processo cuja evolução é determinada pela dinâmica de alianças entre grupos sociais que têm todos eles, interesse em que esse problema seja reconhecido sem que tenham exatamente o mesmo ponto de vista nem sobre o que ele é, nem sobre as medidas a tomar e que, portanto, para se aliar devem negociar sua definição. (PINELL, 2011, p. 239)

Para esse autor, a evolução e a implementação de uma política de saúde é produto da dinâmica de um jogo social complexo, que escapa aos seus formuladores. Sua análise considera quatro fatores interdependentes: 1) as evoluções do front da luta de ordem médica e científica como novos dados sobre a incidência da doença, novos conhecimentos médicos e tratamentos, inovações técnicas e novos tratamentos; 2) as mudanças sociais, de mobilização contra a doença; 3) os efeitos concretos da implementação da política, como a criação 
de novas instituições, grupos profissionais, emergência de novas estruturas associativas; e 4) as mudanças de governo, de manutenção ou mudança da maioria política e mudanças independentes da política em questão, como reformas na saúde, educação e justiça, entre outros.

\section{A grande contribuição de Mário Testa e Carlos Matus}

Entre as correntes marxistas, destaca-se a contribuição teórica de Antonio Gramsci, considerado um neomarxista. Na saúde coletiva latino-americana, destacam-se as contribuições teóricas de Carlos Matus e Mário Testa, que também serão brevemente apresentadas.

O pensamento de Mário Testa e Carlos Matus tem influenciado a reflexão sobre as políticas públicas de saúde no Brasil, especialmente entre aqueles que se debruçam sobre as questões relacionadas ao planejamento em saúde. (PAIM, TEIXEIRA, 2006; VILLASBOAS, PAIM, 2008) Segundo Testa (1992), os desafios da prática impõem aos sujeitos, individuais e coletivos, não só perícia técnica-científica, mas, sobretudo militância sociopolítica, como sujeitos implicados.

Mário Testa centrou seu foco na problemática do poder no setor saúde, o que ele denominou "estrutura de poder no setor saúde". A compreensão do poder é útil para mapeamento dos agentes e análise de suas posições políticas. Para análise do processo político na saúde, o postulado da coerência é uma das suas maiores contribuições. Esta prevê que os propósitos de uma instituição, sua organização e os métodos que utiliza devem apresentar coerência.

Os propósitos de um governo, ocupantes do Estado, podem ser definidos enquanto legitimação, crescimento ou transformação. A legitimação é um propósito permanente dos governos. O crescimento é outro propósito, mas com foco na expansão do governo, sua produtividade. Já o propósito de transformação é o mais desafiador, já que se move na mudança da estrutura social e está relacionado à visão heterogênea do Estado. Os propósitos de legitimação e crescimento estão relacionados à visão de Estado como homogêneo, isto é, a articulação de grupos sociais similares no Estado. Os métodos de governo representam a formalização de uma boa prática, baseada implícita ou explicitamente em uma teoria eficaz. Quanto à organização, esta se constitui como "uma cristalização da história" e está determinada pelo propósito de governo e pelo método. A análise de organização em um dado momento reflete as determinações advindas do passado, juntamente com as atuais onde os outros dois 
elementos (propósito e método) são determinados também pela história, pelo Estado e pela teoria. (TESTA, 1992)

Como principal contribuição de Carlos Matus (1996), podemos situar a proposição da análise permanente do "triângulo de governo" que se conforma em vértices de um triângulo: o projeto de governo, a capacidade de governo e a governabilidade. Para esse importante pensador chileno, a capacidade de governo seria constituída por habilidades, perícia técnica e política, experiências de um ator e sua equipe dirigente para conduzir o processo social, quanto ao seu projeto. O projeto pode ser sinônimo de propósito, no sentido de Mário Testa, representando uma proposição ou conjunto de propostas de ações realizadas por um ator para alcançar metas, de legitimação ou transformação. O terceiro vértice do triângulo de governo, que, somado ao projeto de governo e à capacidade de governo, representam variáveis que se entrelaçam e condicionam-se mutuamente, é a governabilidade.

A governabilidade do sistema é uma relação entre o peso das variáveis que o ator controla e não controla no processo de governo. Quanto mais variáveis o ator controla, maior é sua liberdade de ação e maior é, para ele, a governabilidade do sistema. A governabilidade de um sistema expressa o poder que determinado ator tem para realizar seu projeto. É uma categoria relativa a um determinado ator, às demandas e exigências que o projeto de governo impõe a ele, e à sua capacidade de governo.

Cabe destacar que "ator social" é compreendido por Matus e Testa como pessoa, grupo de pessoas, instituições, organizações sociais ou partidos políticos que se constituem como centros de acumulação e (des-)acumulação de poder com capacidade de produzir fatos sociais e políticos.

Rossi (2015) analisou a configuração da PNSB em dois municípios baianos, a partir da articulação do pensamento de Carlos Matus e Mário Testa. A autora observou observou a existência de projeto de implementação em consonância com as diretrizes do governo local, com propósito de crescimento, alta capacidade de governo e métodos coerentes, além de uma organização favorável à implementação do projeto no municípios com implementação exitosa. Contudo, em outro município, a debilidade do método e um propósito de governo de conservação, aliados às ausências de articulação das variáveis que compõem o triângulo de governo, influenciaram o insucesso na implementação, onde a governabilidade foi ainda menor quando o ator possuía baixa capacidade de governo, sofrendo influências pela fragilidade no projeto de governo que expres- 
sava “conservação” ou legitimação. Esse estudo reforçou o potencial de análise de implementação de política de saúde a partir da contribuição desses autores, também revelado por Chaves e Vieira-da-Silva (2007) e Soares e Paim (2012).

\section{A contribuição Gramsciana}

O conceito de hegemonia foi elaborado por Antônio Gramsci para o estudo dos processos políticos e compreensão das relações de dominação em sociedades capitalistas. Para o autor, o desenvolvimento de um processo hegemônico compreende a constituição inicialmente de um Estado ampliado, cujo estudo das relações entre estrutura e superestrutura se faz necessário. A estrutura é a base econômica da sociedade e a superestrutura se refere à base político ideológica que assegura as condições não materiais, as condições simbólicas para a reprodução da estrutura social, através da ideologia de classe ou frações das classes dominantes. (GRAMSCI, 1978) Nesse sistema, uma determinada classe social detém hegemonia caso ela possua a direção política e ideológica na sociedade civil, utilize da dominação por meio do Estado, caso necessite e, ao mesmo tempo, controle os núcleos centrais da economia. Nos casos em que tal situação se concretize, significa a constituição de um bloco histórico ou um bloco de poder. A distinção realizada por Gramsci entre sociedade civil e política auxilia a compreensão dos fatos e a análise do bloco histórico, que pode facilitar a compreensão dos processos políticos, já que a sociedade política é a arena das instituições políticas de legitimação legal e a sociedade civil é o lugar do "não estatal", organizações cuja função é difundir pensamento hegemônico através de todos os meios de comunicação e instrumentos que permitem influenciar a opinião pública e que inclui a economia. A primeira é a dominação pela força e a segunda, pelo consentimento. Pode-se falar de hegemonia aplicando-a ao campo das relações entre Estados Nacionais, nas relações entre grupos sociais e partidos políticos, em diferentes políticas públicas, como a da saúde bucal, porexemplo.

A constituição de um bloco histórico compreende uma articulação hegemônica onde há interesses de classe, força política coercitiva, e que por sua vez são condicionados pela estrutura que condiciona uma determinada ação política. (GRAMSCI, 2000) A hegemonia é portanto, a concretização da direção que uma classe ou fração de classe exerce sobre a totalidade da sociedade mediante

a coerção ou o consenso. É possível nos jogos de luta, a construção de uma contra-hegemonia, que é organização da própria direção política e ideológica das classes subordinadas para alcançar um novo sistema hegemônico, um novo 
bloco histórico. Essa análise pode ser útil em estudos de políticas públicas setoriais, como a da saúde bucal.

Segundo Bobbio, Mateucci e Pasquino (1991), pode-se encontrar hegemonia fundamentalmente em duas acepções. A primeira associada à ideia de domínio acentuando o uso da força e, portanto da sociedade política, e uma segunda relacionada à direção, acentuando a dimensão intelectual e moral, o consenso, a dimensão cultural; e, por conseguinte a sociedade civil. (BOBBIO, 1991)

Estudo de Vianna (1988) sobre as políticas de saúde bucal no Brasil, nos anos 1970 e 1980, já aponta as dificuldades na implementação de propostas contra-hegemônicas à odontologia dominante, haja vista a dominação simbólica da prática odontológica liberal entre as entidades de classe, em formação naquele período. Burawoy (2010), ao buscar um diálogo entre Gramsci e Bourdieu, aponta grandes semelhanças entre ambos na medida em que estes se preocuparam com a dominação simbólica, além da econômica, através do conceito de superestrutura político-ideológica em Gramsci (a chamada superestrutura no marxismo clássico) e de violência simbólica em Pierre Bourdieu. A sociedade civil em Gramsci se assemelha ao conceito do campo do poder em Bourdieu, como espaço dos dominantes dos diversos espaços sociais, que disputam a ocupação do Estado.

\section{Os estudos de análise das políticas de saúde bucal no Brasil}

No Brasil, muito recentemente, o tema da análise política em saúde bucal tem sido objeto de interesse de alguns pesquisadores. O Quadro 1 sistematiza a produção científica recente em análise política sobre a atual PNSB no âmbito nacional. Não foram aqui incluídos estudos de análise de resultados ou do processo, com os estudos quantitativos. Apenas foram incluídos estudos que buscaram produzir análise política, na política de saúde bucal, ou seja, que se debruçaram sobre as relações e processos de acumulação e (des-)acumulação de poder e outros capitais que resultaram em caminhos: na entrada na agenda, na apresentação de alternativas, na sua formulação ou implementação, compreendido, nesse contexto, como etapas do ciclo da política.

Aqui, consideramos que o espaço "da saúde bucal” ou "da política de saúde bucal" é um espaço social onde as diversas instituições e agentes engajados pertencem a diferentes campos, com distintos interesses em jogo que podem ter efeitos nos resultados dessa implementação. O Quadro 1 apenas reflete o campo científico, espaço de relações entre agentes interessados na produção e legitima- 
ção do conhecimento da política. Neste, não foi objeto de análise os diferentes pontos de vista do campo burocrático, ou seja, do espaço onde se situa os funcionários dos governos que formulam e implementam a política pública.

Os dois primeiros estudos foram duas dissertações de mestrado defendidas no Instituto de Medicina Social da Universidade Estadual do Rio de Janeiro. (BARTOLE, 2006; GARCIA, 2013) Esta última publicou parte desse trabalho em 2013. (GARCIA, 2013) O principal referencial de análise política em ambos os trabalhos foi o neoinstitucionalismo em que as autoras identificaram dois processos de formulação de políticas distintos: a entrada da saúde bucal no Programa de Saúde da Família, em 2000, e a PNSB Brasil Sorridente, em 2004. A principal contribuição de Bartole (2006) foi identificar esses momentos como "janela de oportunidade", compreendida como situações que favorecem a convergência da construção social do problema da saúde bucal, das alternativas para seu enfrentamento num clima político favorável para a tomada de decisão, formando a agenda governamental e posteriormente decisória. Também houve a atuação de atores dos movimentos políticos, incluindo o movimento sanitário, compromissados com a saúde bucal e reconhecidos como um grupo com forte matiz político-partidária fora do espaço institucional do governo e posteriormente, dentro dele. (GARCIA, 2013) Andrade (2009) e Rendeiro (2011) também chegam às mesmas conclusões, ainda que com referenciais de análise política distintos. O primeiro (ANDRADE, 2009), em uma dissertação de mestrado, publicada posteriormente em formato de livro pela editora da Universidade Federal de Goiás, reafirma a força desse grupo a partir da categoria poder em Hannah Arendt, como atributo central de grupos que constroem vontade comum. A conclusão é que foi um processo envolvendo agentes sociais engajados na militância política que construíram a proposta, com poucas alternativas. O grupo inicial produziu vontade comum, ou poder no sentido arendtiano (ANDRADE, 2009), mas também foi considerado como uma comunidade epistêmica. (RENDEIRO, 2011) Este último trabalho foi uma tese de doutorado defendida na Escola Nacional de Saúde Pública, de referencial neoinstitucionalista.

Em síntese, os estudos sobre a entrada na agenda apresentam duas vertentes, não excludentes entre si: a oficial, que aponta que os dados dos inquéritos epidemiológicos, como o alto percentual de perda dental entre adultos e a 
baixa percentagem de procedimentos odontológicos especializados no sistema público, subsidiaram de forma relevante a construção da PNSB; e outra que defende que a entrada na agenda e a formulação de algumas alternativas políticas resultou da atuação de distintos grupos de interesse, com participação ativa da comunidade epistêmica (RENDEIRO, 2011), os militantes de esquerda e pesquisadores (BARTOLE, 2006; GARCIA, 2013), bem como do "poder emanado de um grupo de pessoas que age em comum acordo, com legitimidade da reunião inicial" (ARENDT, 1985, p. 28), por referência ao encontro inicial que foi a reunião de São Paulo, em 2002, quando um grupo de militantes elaborou um documento a ser entregue ao presidente Lula, recém-eleito.

A produção de conhecimento sobre os processos políticos envolvidos na implementação e avaliação da política no Brasil, tanto no nível estadual e municipal, não foi foco deste capítulo em particular. Pouco se sabe a esse respeito. Esforços devem ser empreendidos pelos pesquisadores e gestores no sentido da incorporação da melhor teoria possível para produzir o êxito em todo o ciclo da política pública. Reconhecer e compreender as relações de poder e dominação em jogo entre os agentes sociais interessados já é um grande primeiro passo para a transformação das relações de dominação simbólica.

\section{Referências}

ANDRADE, F. R. Relações de poder na Política Nacional de Saúde Bucal. Goiania: Editora UFG, 2009. (Coleção Expressão Acadêmica).

ARENDT, H. Da violência. Brasília: Editora Universidade de Brasília, 1985.

ARENDT, H. Poder e violência. Rio de Janeiro, Relume Dumará, 2001. p. 81-94.

AROUCA, S. O dilema preventivista: contribuição para a compreensão e crítica da medicina preventiva. Rio de Janeiro: Fiocruz/Unesp, 2007.

ASSIS, L. N. de. Politicas de saude bucal no periodo pos-constituinte (1988-2004). 2006. 392 f. Dissertação (Mestrado em Saúde Coletiva) - Instituto de Saude Coletiva, Universidade Federal da Bahia, Salvador, 2006.

BARROS, S. G. A política nacional de luta contra a aids e o espaço aids no Brasil. 2013. $274 \mathrm{f}$. Tese (Doutorado em Saúde Coletiva) - Instituto de Saúde Coletiva, Universidade Federal da Bahia, Salvador, 2013.

BARTOLE, M. C. S. A construção da política Nacional de Saúde Bucal: percorrendo os bastidores do processo de formulação 2000-2004. 2006. 104 f. Dissertação (Mestrado em Saúde Coletiva) - Instituto de Medicina Social, Universidade do Estado do Rio de Janeiro, Rio de Janeiro, 2006 
BOBBIO, N.; MATEUCCI, N.; PASQUINO, G. Dicionário de Política. 3. ed. Brasília: Editora UNB, 1991. p. 579-581. v. 1.

BOURDIEU, P. Razões práticas: sobre a teoria da ação. 6. ed. Campinas, SP: Papirus; 1996 BOURDIEU, P. Pontos de referências. In: BOURDIEU, P. Coisas ditas. Tradução Cássia Silveira e Denise Pegorim. São Paulo: Brasiliense, 2004. p. 49-73.

BOURDIEU, P. Questões de sociologia. Lisboa: Fim de Século, 2003.

BOURDIEU, P. Sobre o estado. São Paulo: Companhia das Letras, 2014.

BURAWOY, M. O marxismo encontra Bourdieu. Tradução Fernando Rogério Jardim. Campinas: Editora da Unicamp, 2010. 183p.

CARVALHO, L. A. C et al. Procedimentos coletivos de saúde bucal: gênese, apogeu e ocaso. Saúde e Sociedade, São Paulo, v. 18, n. 3, p. 490-499, 2009. Disponível em: <http:// www.scielo.br/scielo.php?script=sci_arttext\&pid=So104-12902009000300013>. Acesso em: 14 jun. 2016.

CHAVES, S. C. L.; VIEIRA-DA-SILVA, L. M. As práticas profissionais no campo público de atenção à saúde bucal: o caso de dois municípios da Bahia.Ciênia \& saúde coletiva, Rio de Janeiro, v. 12, n. 6, p. 1697-1710, dez. 2007.

CHAZEL, F. Poder. Tratado de Sociologia. Org. Raymond Boudon. Rio de Janeiro: Jorge Zahar Editor. 1995 .

FISHER, F.; MILLER, G. J.; SIDNEY, M. S. Handbook of public cpolicy analysis: theory, politics, and methods. Part II policyprocess. Boca Raton: CRC Press, 2007.

GARCIA, D. V. Sobre os bastidores do processo de formulação de políticas públicas: considerações acerca da saúde bucal no Brasil. Revista de Políticas Públicas. São Luis, v. 17, n. 1, p. 203-209, jan./jun., 2013.

GIDDENS, A. Central Problems in Social Theory. London: Macmillan, 1978.

GRAMSCI, A. Cadernos do cárcere. Rio de Janeiro: Civilização Brasileira, 1978. v. 2.

GRAMSCI, A. Cadernos do cárcere. Tradução Carlos Nelson Coutinho. Rio de Janeiro: Civilização Brasileira, 2000. v. 3.

HABERMAS, J. The theory of communicative action. Reason and the rationalizalion of society. Boston: Beacon Press, 1984. v. 1.

KINGDON, J. Agendas, alternatives, and public policies. New York: Logman, 1995.

LIMA, L. D.; MACHADO, C. V.; GERASSI, C. D. O neo-institucionalismo e a análise de políticas de saúde: contribuições para uma reflexão crítica. In: MATTOS, R. A.; BAPTISTA, T. W. (Org.). Caminhos para análise das políticas de saúde, 2011. Disponível em: <www.ims. uerj.br>. Acesso em: 16 maio 2016.

LIMA, W. G. Política pública: discussão de conceitos. Interface, Porto Nacional, n. 5, p. 4954, out. 2012.

MARX, K.; ENGELS, F. Manifesto do Partido Comunista. 9. ed. Petrópolis, RJ: Vozes, 1999. 
MATUS, C. Política, planejamento e governo. 2. ed. Brasília, DF: Instituto de Pesquisa Econômica Aplicada, 1996.

MOYSÉS S. J et al. Avanços e desafios à política de vigilância à saúde bucal no Brasil. Revista de Saúde Pública, São Paulo, v. 47, suppl. 3, p. 161-167, 2013, Disponível em: <http:// www.scielo.br/pdf/rsp/v47s3/0034-8910-rsp-47-supl3-00161.pdf>. Acesso em: 16 maio 2016.

PAIM, J. S. Políticas de saúde no Brasil. In: ROUQUAYROL, M. Z.; ALMEIDA FILHO, N. Epidemiologia e saúde. 6. ed. Rio de Janeiro: MEDSI, 2003. p. 587-603.

PAIM, J. S.; TEIXEIRA, C. F. Política, planejamento e gestão em saúde: balanço do estado da arte. Revista de Saúde Pública, São Paulo, v. 40, n. Esp., p. 73-78, agosto 2006.

PAIM, J. S. Saúde política e reforma sanitária. Salvador: ISC-CEPS, 2002. v. 1.

PINELL, P. Algumas reflexões sobre as políticas de luta contra os flagelos sociais. In: PINELL, P. Análise sociológica das políticas de saúde. Rio de Janeiro: Editora Fiocruz, 2011. p. 229-250.

PIRES, F. S.; BOTAZZO, C. Organização tecnológica do trabalho em saúde bucal no SUS: uma arqueologia da política nacional de saúde bucal. Saúde e Sociedade, São Paulo, v. 24, n. 1, p. 273-284, mar. 2015 .

PLATÃO. A República. Tradução Anna Lia Amaral de Almeida Prado. São Paulo: Martins Fontes, 2006.

RENDEIRO, M. M. P. O ciclo da Política de Saúde Bucal no Sistema Público Brasileiro: atores, idéias e instituições. 2011. 188 f. Tese (Doutorado em Saúde Coletiva) - Escola Nacional de Saúde Pública Sergio Arouca, Rio de Janeiro, 2011.

ROSSI, T. R. A; CHAVES, S. C. L. A política de saúde bucal na atenção especializada em dois municípios da Bahia: da entrada na agenda à sua implementação. Revista Saúde em Debate, Rio de Janeiro, v. 39, n. spe, p. 196-206, dez. 2015

SABATIER, P. A.Theories of the policy process. Boulder, CO: West view Press. 2007.

SOARES, C. L. M. Constructing public oral health policies in Brazil: issues for reflection. Brazilian Oral Research, São Paulo, v. 26, n. spe1, p. 94-102. 2012. Disponível em: $<$ http://www.scielo.br/scielo.php?script=sci_arttext\&pid=S1806-83242012000700014>. Acesso em: 16 maio 2016.

SOARES, C. L. M. ; PAIM, J. S. Aspectos críticos para a implementação da política de saúde bucal no Município de Salvador, Bahia, Brasil. Cadernos de Saúd Pública, Rio de Janeiro, v. 27, n. 5, p. 966-974, maio, 2011.

SOUZA, C. Estado da arte da pesquisa em políticas públicas. In: HOCHMAN, G.; ARRETCHE, M.; MARQUES, E. Políticas públicas no Brasil. Rio de Janeiro: Editora FioCruz, 2007.

TESTA, M. Pensamento estratégico e lógica da programação. Rio de Janeiro: São Paulo: HUCITEC, 1995.

TESTA, M. Pensar em saúde. Porto Alegre: Artes Médicas: ABRASCO, 1992. 
VIANNA, M. I. P. Estado e atenção odontológica no Brasil: um estudo sobre as políticas de saúde bucal na conjuntura pós-74. 211 f. (Mestrado em Saúde Comunitária) - Instituto de Saúde Coletiva, Universidade Federal da Bahia, Salvador, 1988.

VIEIRA-DA-SILVA, L. M. Avaliação de políticas e programas de saúde. Rio de Janeiro: Editora Fiocruz; 2014. (Temas em Saúde Coletiva)

VILASBOAS, A. L. Q.; PAIM, J. S. Práticas de planejamento e implementação de políticas no âmbito municipal. Cadernos de Saúde Pública, Rio de Janeiro, v. 24, n. 6, p. 12391250, jun. 2008.

WALT, G. et al. Doing' health policy analysis: methodological and conceptual reflections and challenges. Health Policy and Planning, Oxford, v. 23, p. 308-317, 2008.

WEBER, M. Economia e sociedade. Brasília: Editora UNB, 2004. v. 2.

WEBER, M. Ciência e política: duas vocações. 21. ed. São Paulo: Editora Cultrix, 2014. 


\section{Quadro 1 - Estudos de análise política em saúde bucal no Brasil, no século XXI, no âmbito nacional, a partir do momento do ciclo da política, abordagem teórico-metodológica e principais conclusões \\ (continua)}

\begin{tabular}{|c|c|c|}
\hline Autor, ano & $\begin{array}{l}\text { Garcia, D. do V. 2006. A construção da política nacional de saúde } \\
\text { bucal percorrendo os bastidores do processo de formulação. } \\
(2000-2004) \\
\text { IMS-UERJ }\end{array}$ & $\begin{array}{c}\text { Bartole, M. C. S. 2006. [dissertação de mestrado]. Da } \\
\text { boca cheia de dentes ao Brasil Sorridente: uma análise } \\
\text { retórica da formulação da política nacional de saúde } \\
\text { bucal. } \\
\text { IMS-UERJ }\end{array}$ \\
\hline $\begin{array}{l}\text { Ciclo da política/ } \\
\text { período }\end{array}$ & $\begin{array}{l}\text { Entrada na agenda } \\
\text { Formulação } \\
\text { 2000-2004 }\end{array}$ & $\begin{array}{l}\text { Entrada na agenda } \\
\text { Formulação } \\
\text { 2000-2004 }\end{array}$ \\
\hline $\begin{array}{l}\text { Abordagem teórico- } \\
\text { metodológica e } \\
\text { conceitos-chave }\end{array}$ & $\begin{array}{l}\text { Neoinstitucionalismo. Análise do ator institucional, Ministério da } \\
\text { Saúde, análise de documentos oficiais e entrevistas com atores } \\
\text { privilegiados. } \\
\text { Ator institucional, a coordenação nacional de saúde bucal, janela } \\
\text { de oportunidade. Agenda. }\end{array}$ & $\begin{array}{l}\text { Análise dos discursos que compuseram a processo de } \\
\text { formulação. Análise da retórica dos documentos para } \\
\text { observar o processo político. }\end{array}$ \\
\hline Principais conclusões & $\begin{array}{c}\text { Dois processos de formulação de políticas distintos: a entrada da } \\
\text { saúde bucal no PSF em } 2000 \text { e a PNSB Brasil Sorridente, em } 2004 . \\
\text { No primeiro, aproveitamento de uma janela de oportunidades } \\
\text { por técnicos ligados à saúde bucal. No segundo, um processo } \\
\text { de construção de um projeto por um grupo com forte matiz } \\
\text { político-partidária, fora do espaço institucional do governo e } \\
\text { posteriormente, dentro dele. }\end{array}$ & $\begin{array}{l}\text { Destacaram-se a existência de dois processos de } \\
\text { formulação de políticas distintos que foram: a entrada } \\
\text { da saúde bucal no PSF e a PNSB Brasil Sorridente. }\end{array}$ \\
\hline
\end{tabular}


Quadro 1 - Estudos de análise política em saúde bucal no Brasil, no século XXI, no âmbito nacional, a partir do momento do ciclo da política, abordagem teórico-metodológica e principais conclusões

(continuação)

\begin{tabular}{|c|c|}
\hline Autor, ano & $\begin{array}{l}\text { Andrade, F. R. de.2009. [dissertação de mestrado]. } \\
\text { Relações de poder na política nacional de saúde bucal. UFG }\end{array}$ \\
\hline Ciclo da política/período & $\begin{array}{l}\text { Entrada na agenda } \\
\text { Formulação } \\
\text { 2002-2004 }\end{array}$ \\
\hline $\begin{array}{l}\text { Abordagem teórico- } \\
\text { metodológica e } \\
\text { conceitos-chave }\end{array}$ & $\begin{array}{l}\text { Estudo com abordagem qualitativa que analisou as relações de poder na elaboração da PNSB. Foram conduzidas } \\
\text { entrevistas semiestruturadas com } 15 \text { atores. Conceitos ou categorias chave: atores participantes, tipo de participação, } \\
\text { início da elaboração, arenas de discussão, contexto político, impasses atuais e perspectivas. Poder na concepção } \\
\text { arendtiana, como atributo de grupos que constroem vontade comum, foi central. }\end{array}$ \\
\hline Principais conclusões & $\begin{array}{l}\text { Os atores participantes encontram-se divididos em dois grupos: individuais e coletivos. O primeiro deles, coeso, é } \\
\text { formado por indivíduos identificados com o projeto político vitorioso nas eleições presidenciais de } 2002 \text { e que possuem } \\
\text { um passado de militância na construção do Sistema Único de Saúde (SUS). A PNSB foi resultado de reflexões desde } \\
\text { o Movimento da Reforma Sanitária, com destaque para um encontro realizado no município de São Paulo logo após o } \\
\text { resultado do pleito eleitoral referente à candidatura à presidência da República de Lula em 2002. Essa reunião definiu a } \\
\text { proposta que foi apresentada aos membros da Comissão de Transição Governamental. }\end{array}$ \\
\hline
\end{tabular}




\section{Quadro 1 - Estudos de análise política em saúde bucal no Brasil, no século XXI, no âmbito nacional, a partir do momento do ciclo da política, abordagem teórico-metodológica e principais conclusões \\ (continuação)}

\begin{tabular}{|c|c|}
\hline Autor, ano & $\begin{array}{l}\text { Rendeiro, M., 2011. [tese de doutorado]. } \\
\text { O ciclo da política de saúde bucal no sistema de saúde brasileiro: atores, ideias e Instituições. } \\
\text { ENSP-FIOCRUZ }\end{array}$ \\
\hline $\begin{array}{l}\text { Ciclo da política/ } \\
\text { período }\end{array}$ & $\begin{array}{l}\text { Entrada na agenda } \\
\text { Formulação } \\
\text { 2000-2010 }\end{array}$ \\
\hline $\begin{array}{l}\text { Abordagem teórico- } \\
\text { metodológica e } \\
\text { conceitos-chave }\end{array}$ & $\begin{array}{l}\text { Neoinstitucionalismo, com foco nos atores, ideias e instituições, verificando as características do processo, as ideias, } \\
\text { atores e instituições. Entrevistas com } 12 \text { informantes-chave e dados secundários, por meio da pesquisa documental } \\
\text { e acesso aos bancos de dados do DATASUS, além da pesquisa documental. Empreendedor de políticas. Comunidade } \\
\text { epistêmica (acadêmicos, pesquisadores, consultores, sindicalistas, profissionais das SES e SMS), construída ao longo } \\
\text { de um processo histórico, que envolveu a militância político-partidária e setorial. Grupos de Interesse. Conceitos-chave: } \\
\text { Inovação como a provisão em larga escala de novos serviços na área da odontologia. Governo. Ator social. }\end{array}$ \\
\hline Principais conclusões & $\begin{array}{l}\text { Identificou três ciclos de inovação: saúde bucal no PACS, saúde bucal no PSF, em 2000, e a publicação das diretrizes da } \\
\text { PNSB, em } 2003 \text {. A saúde bucal chegou à agenda decisória, como resultado de fato social e político da Pesquisa Nacional } \\
\text { por Amostra de Domicílios } 2008 \text { com continuidade de trajetória. Houve formação incremental do ciclo da PNSB por meio } \\
\text { de inovações progressivamente inseridas, com influência dos partidos hegemônicos das coligações presidenciais e com } \\
\text { a participação de atores associados aos interesses da classe odontológica. Houve um empreendedor de políticas que } \\
\text { articulou a comunidade epistêmica com o chefe do executivo no terceiro ciclo. Sem elementos do controle social. }\end{array}$ \\
\hline
\end{tabular}




\section{Quadro 1 - Estudos de análise política em saúde bucal no Brasil, no século XXI, no âmbito nacional, a partir do momento do} ciclo da política, abordagem teórico-metodológica e principais conclusões

(continuação)

\begin{tabular}{|c|c|}
\hline Autor, ano & $\begin{array}{l}\text { Carvalho, L. A. C. et al. 2009. [artigo]. } \\
\text { Procedimentos coletivos de saúde bucal: gênese, apogeu e o caso. } \\
\text { FSP-USP }\end{array}$ \\
\hline $\begin{array}{l}\text { Ciclo da política/ } \\
\text { período }\end{array}$ & $\begin{array}{l}\text { Formulação } \\
\text { Implementação } \\
\text { 1994-2006 }\end{array}$ \\
\hline $\begin{array}{l}\text { Abordagem teórico- } \\
\text { metodológica e } \\
\text { conceitos-chave }\end{array}$ & $\begin{array}{l}\text { Não explicita o referencial teórico. Estudo de natureza descritiva com revelação dos principais agentes envolvidos com sua } \\
\text { gênese e implementação. Fonte de dados: pesquisa bibliográfica e análise documental, abrangendo o período de } 1991 \text { a } \\
2006 .\end{array}$ \\
\hline Principais conclusões & $\begin{array}{l}\text { O procedimento coletivo foi criado no governo Collor (1990-1992), no pós Lei no 8080/90, na gestão Sérgio Weyne. } \\
\text { Pagamento por procedimento de ações de promoção e prevenção em saúde bucal em todos municípios brasileiros. A } \\
\text { coincidência com um período de intensificação do processo de municipalização das ações e dos serviços de saúde por } \\
\text { certo potencializou esse efeito. Contribuiu para diversificar o modelo de prática odontológica predominante no setor } \\
\text { público, redirecionando-o para ações preventivas e de promoção da saúde. }\end{array}$ \\
\hline
\end{tabular}




\section{Quadro 1 - Estudos de análise política em saúde bucal no Brasil, no século XXI, no âmbito nacional, a partir do momento do}

ciclo da política, abordagem teórico-metodológica e principais conclusões

(continuação)

\begin{tabular}{|c|c|}
\hline Autor, ano & $\begin{array}{l}\text { Assis, L. N. 2006. [dissertação de mestrado]. } \\
\text { Politicas de saúde bucal no período pós-constituinte (1988-2004). } \\
\text { ISC-UFBA }\end{array}$ \\
\hline $\begin{array}{l}\text { Ciclo da política/ } \\
\text { período }\end{array}$ & $\begin{array}{c}\text { Implementação } \\
\text { 1999-2004 }\end{array}$ \\
\hline $\begin{array}{l}\text { Abordagem teórico- } \\
\text { metodológica e } \\
\text { conceitos-chave }\end{array}$ & $\begin{array}{l}\text { Identifica os principais fatos políticos em saúde bucal produzidos no âmbito dos governos dos presidentes Fernando } \\
\text { Henrique Cardoso (1999-2002) e Luís Inácio Lula da Silva (2003-2004), a partir dos componentes do sistema de saúde } \\
\text { como gestão, financiamento, organização, infraestrutura e modelo de atenção estudo de caso, de base documental. Fonte } \\
\text { de dados: leis, projetos de lei, normas, portarias, decretos, medidas provisórias, manuais, relatórios, referentes à atenção à } \\
\text { saúde bucal. }\end{array}$ \\
\hline Principais conclusões & $\begin{array}{l}\text { Evolução das políticas de saúde bucal formuladas e implementadas nos governos FHC e Lula, porém, pode-se inferir que } \\
\text { a viabilidade a longo prazo da odontologia no SUS apresenta a mesma limitação tratada por Vianna diante do caráter } \\
\text { secundário dessas políticas, que concorrem com políticas de maior gravidade da saúde. Dentre os componentes do sistema } \\
\text { de saúde, o modelo de atenção continua sendo o mais problemático. }\end{array}$ \\
\hline
\end{tabular}




\section{Quadro 1 - Estudos de análise política em saúde bucal no Brasil, no século XXI, no âmbito nacional, a partir do momento do} ciclo da política, abordagem teórico-metodológica e principais conclusões

(continuação)

\begin{tabular}{|c|c|}
\hline Autor, ano & $\begin{array}{c}\text { Pires F. S., Botazzo C. 2015. [artigo]. Organização tecnológica do trabalho em saúde bucal no SUS: uma arqueologia da } \\
\text { política nacional de saúde bucal. Saúde Sociedade, USP-SP }\end{array}$ \\
\hline $\begin{array}{l}\text { Ciclo da política/ } \\
\text { período }\end{array}$ & $\begin{array}{l}\text { Implementação } \\
\text { nacional } \\
\text { 2000-2012 }\end{array}$ \\
\hline $\begin{array}{l}\text { Abordagem teórico- } \\
\text { metodológica e } \\
\text { conceitos-chave }\end{array}$ & $\begin{array}{l}\text { Discute a organização tecnológica dos modelos de atenção à saúde bucal à luz da PNSB. O referencial teórico-- } \\
\text { metodológico estruturou-se em um histórico das políticas de saúde bucal no Brasil, buscando apreender o saber operante } \\
\text { que norteou a prática neste campo. A abordagem das políticas de saúde foi realizada sob a teoria de Michel Foucault na } \\
\text { obra Arqueologia do Saber. Utilizou-se de revisão de documentos normativos do SUS e de publicações do período de } 2000 \\
\text { a } 2012 .\end{array}$ \\
\hline Principais conclusões & $\begin{array}{l}\text { O levantamento de artigos sobre a atual PNSB destacou nos serviços um modus operandi calcado na pragmática prática } \\
\text { odontológica, plena de conflitos e contradições. Para que as diretrizes da PNSB transformem a prática em saúde bucal com } \\
\text { novos arranjos tecnológicos no processo de trabalho, outras formas de vínculo e comprometimento devem ser almejadas. } \\
\text { A pesquisa conclui que é necessário repensar a tecnologia do cuidado em saúde bucal como possibilidade da atenção com } \\
\text { integralidade e de sua legitimação como um dos componentes da saúde em uma expressão ampliada: a da qualidade de vida. }\end{array}$ \\
\hline
\end{tabular}




\section{Quadro 1 - Estudos de análise política em saúde bucal no Brasil, no século XXI, no âmbito nacional, a partir do momento do}

ciclo da política, abordagem teórico-metodológica e principais conclusões

(continuação)

\begin{tabular}{|c|c|}
\hline Autor, ano & Moysés S. J et al. 2013. Avanços e desafios à política de vigilância à saúde bucal no Brasil. PUC-PR. \\
\hline $\begin{array}{l}\text { Ciclo da política/ } \\
\text { período }\end{array}$ & $\begin{array}{l}\text { Implementação vigilância à saúde bucal } \\
2009-2010\end{array}$ \\
\hline $\begin{array}{l}\text { Abordagem teórico- } \\
\text { metodológica e } \\
\text { conceitos-chave }\end{array}$ & $\begin{array}{c}\text { Pesquisa participante. Revisão crítica e integrativa, de caráter descritivo-discursivo, dedicada à explanação da política de } \\
\text { vigilância à saúde bucal vigente no Brasil. Com base em uma apreciação crítica dos trabalhos nacionais e internacionais, } \\
\text { examina-se a formulação de uma agenda política e científica em vigilância à saúde bucal, ancorada na institucionalidade do } \\
\text { SUS. }\end{array}$ \\
\hline Principais conclusões & $\begin{array}{l}\text { A efetivação da referida agenda é exemplificada com a apresentação da Pesquisa Nacional de Saúde Bucal (SBBrasil 2010), } \\
\text { que evidenciou que é possível construir política e operacionalmente maior integração entre a academia e os serviços de } \\
\text { saúde. A implementação da vigilância à saúde bucal, integrada estrategicamente ao SNVS, traduz-se em um elemento } \\
\text { essencial para a sustentabilidade da PNSB e para o progressivo reconhecimento das boas práticas do SUS pela população. }\end{array}$ \\
\hline
\end{tabular}




\section{Quadro 1 - Estudos de análise política em saúde bucal no Brasil, no século XXI, no âmbito nacional, a partir do momento do ciclo da política, abordagem teórico-metodológica e principais conclusões \\ (conclusão)}

\begin{tabular}{|c|c|}
\hline Autor, ano & $\begin{array}{l}\text { Soares, C. L. M. 2012. Constructing public oral health policies in Brazil: issues for reflection. Braz. oral res., } \\
\text { ISC-UFBA }\end{array}$ \\
\hline $\begin{array}{l}\text { Ciclo da política/ } \\
\text { período }\end{array}$ & $\begin{array}{l}\text { Implementação } \\
\text { histórico das políticas }\end{array}$ \\
\hline $\begin{array}{l}\text { Abordagem teórico- } \\
\text { metodológica e } \\
\text { conceitos-chave }\end{array}$ & $\begin{array}{l}\text { Análise documental, buscando identificar os principais movimentos ideológicos em saúde bucal no mundo que tiveram } \\
\text { influência no Brasil, relacionando com as respostas estatais em saúde bucal no Brasil ao longo do século XX e no início XXI, } \\
\text { destacando-se a PNSB formulada em 2004. Conceito de movimentos ideológicos como um conjunto de atividades visando } \\
\text { transformar a "visão de mundo" em uma “nova visão de mundo" com um corpo coerente de ideias (Arouca, 2007), e de } \\
\text { hegemonia (Gramsci, 1996). }\end{array}$ \\
\hline Principais conclusões & $\begin{array}{l}\text { O estudo identificou quatro movimentos ideológicos relacionados às políticas públicas de saúde bucal no Brasil, mas } \\
\text { revelou a hegemonia das ideias em torno da odontologia de mercado, ou odontologia privada mesmo ao interior dos } \\
\text { serviços públicos. Dentre os movimentos ao interior do serviço público, identificou-se a odontologia sanitária ou social. } \\
\text { A odontologia simplificada, a odontologia preventiva e social e o movimento da saúde bucal coletiva. Ainda que haja } \\
\text { progressiva expansão da intervenção do Estado nas políticas de saúde bucal, é observado que continua hegemônica a } \\
\text { prática da odontologia privada no setor público e na estratégia de saúde da família. }\end{array}$ \\
\hline
\end{tabular}

Fonte: bases de dados Lilacs e Scielo. 